\title{
Petrol Price: Pre \& Post Goods and Services Tax (GST) in India
}

\author{
S. Saravanakumar, R. Kiruba Shankari
}

\begin{abstract}
Goods and services tax is an all-inclusive tax levied on manufacturing, sales and consumptions of goods and services within a country, introduced by the Indian President on 1st July 2017, which subsumed all indirect taxes levied by both Governments(the central and the state). However petrol was kept out of GST framework in order to preserve the revenue acquired by the state. the present study gives you the answers for the questions like what is GST?, What is the reason for not implementing GST on petrol? What will be the price of one liter petrol when the same is subsumed in GST? This paper highlights the comparison between the present tax rate on petrol and the rate at which petrol would cost when it is subsumed by the GST.
\end{abstract}

Keywords: GST, no GST on petrol, revenue, comparison on GST rates.

\section{INTRODUCTION}

$\mathrm{T}$ he country to implement the GST for the first time was France in 1954. Now, in India, the tax amend has been taken over by the Indian government characterizing some historical moves. India's colossal tax reform - Goods and services $\operatorname{Tax}(\mathrm{GST})$ is a one nation, one tax system. A committee was formed in 2000 by Atal Bihari Vajpayeee which was conducted under the chairmanship of the Finance minister for scrutiny on GST, in which the duty to prepare complete portrait of GST was given.The Goods and Services Tax Act was originated on 29th March 2017in the Parliament. But the Act came into effect in India from 1st July, 2017. The primary aim of introducing the GST is to get a consistent indirect tax structure. The basis to share the actual tax collection as FST is $50-50$ between the Centre and the States. There are four slabs within which the total taxation on goods or services has to fit into. They are 5\%,12\%, 18\% or $28 \%$.There are 4 types of GST. They are Central Goods and Services Tax(CGST) - shared to the Central authority body, State Goods and Services Tax (SGST) - Shared to State authority body, Integrated Goods and Services Tax(IGST) Shared to Central and State authority body, Union Territory Goods and Services Tax (UTGST).

\section{A. Reason for not Adding Petrol on GST Regime}

In India, the Price on petrol is not constant. It fluctuates day by day. The major factor is that the production of oil in the OPEC (Organization of the Petroleum Exporting Countries) and hike in crude oil price in the international

Revised Manuscript Received on December 05, 2019.

* Correspondence Author

Dr. S. Saravanakumar*, Annai Theara Arts and Science College, Mangalam, Tamil Nadu, India.

R. Kiruba Shankari, Annai Theara Arts and Science College, Mangalam, Tamil Nadu, India.
market.On a meeting, All India Petroleum Dealers Association President Ajay Bansal said that they can only control the rising fuel price by reducing VAT of State and Central taxes.Petrol price varies from state to state depending on the factors like VAT and local sales tax. Each and every change in such price would result changes in State VAT as it is computed on the net price after adding dealers' commission, excise duty and petrol pump commission.At present, the effective sales tax by states ranges from $6 \%$ to $40 \%$ on petrol. This means that every hike in crude price brings more revenue to the states. Once subsumed in GST, fuels will cost the same across the country.

Tax on petroleum products is one of the major sources of revenue earned by both Central and State Government. If petrol is taxed under GST, this revenue would be cut down into half. The highest tax slab in GST is $28 \%$ which is shared between Central and State Government. States were feared that they would face heavy loss of revenue as the state-level taxes on petrol being interrupted. GST may affect the state by incorporating all the state level taxes like VAT, sales tax, purchase tax, entertainment tax, octroi duty, entry tax, luxury tax, \& taxes on gambling and lottery.

Another reason is that the State Government taxes very low in some /States. If they accept GST on petrol, the tax rate at present may be increased which causes dissatisfaction and anger among the people belonging to that State. This made the Government get fear that their party may not get another chance to rule the State again.

\section{B. Petrol Price Before and After GST}

GST is an utilization based tax imposed on the supply of goods and services which mean that it will be levied at each\& every stage of sale or purchase of goods or services based on the input tax credit system.Currently, petrol, diesel, crude oil, natural gas and aviation turbine fuel (ATF) are excluded from the purview of goods \& services tax; hence petrol is levied tax by both governments (Central Government as excise duty and State Government as value added tax).Petrol and diesel is an important resource for transporting the goods. Nowadays, it is difficult to the business which is using petrol and diesel as one of the main source to claim the input tax credit on which they have paid for purchasing petrol and diesel. Manufacturers are able to save some amount of tax as input tax credit on GST when they pay tax on their produced goods or services. This is because they would have already imposed and paid for the same products during the purchases. So, during payment of tax on finished goods, the manufacturers are able to claim discount for the tax that they have paid on raw materials. 
Margins of small businesses can be increased by their input tax credit system by GST.In crude terms, WTI is sweet, low sulphur, Brent has higher sulphur as such less sweeter than WTI, but denser than WTI. Brent is considered to be of better quality for petrol and diesel distillates, Brent is more expensive than WTI and Brent is what India imports.In India, petrol price is revised and increasing day by day. This is due to the change in crude oil price. The price of Crude oil is Rs.5872 or \$ 82.21 per barrel. 1 barrel = 159 lit. Hence, Petrol price per lit available to the dealers is Rs.37 per liter 5 . (Mukherjee, S., \& Rao, R. K. (2019).

After this certain amount of dealers commission is added followed by the Central excise duty of a certain fixed amount, and value added tax levied by each state.

\section{REVIEW OF LITERATURE}

Rao, R. K., \& Mukherjee, S. (2019) stated that Goods and Services Tax (GST) introduction will affect the country like India due to eighty percentage of state government revenues are cascading due to the adoption of uniform rates in India. Keshap, P. K. (2015) discussed the Indian entry to regime of GST from $1^{\text {st }}$ April 2016 was quietly affecting the different types of industries such as, marketing, manufacturing and sales companies for many deliverables. Further the author stated that introduction of GST will replaced multiple indirect tax system in the country with single tax system. The author opined that elimination of GST will reduce boost the India's GDP for $0.9 \%$ to $1.7 \%$. Sakharam Mujalde and Avi Vani (2017) measured the GST outcome in India and discussed that GST was helped the policy makers to overcome the shortcomings in the earlier Value Added Tax (VAT). Monika Sehrawat (2015) studied the implementation of GST as a key factor for grabbing the various types of treatments for manufacturing and services sector in India.

\section{OBJECTIVES OF THE STUDY}

- This study primarily aims to compare the price of petrol in the state of Tamil Nadu before and after introduction Goods and Services Tax (GST).

\section{RESULTS AND DISCUSSION}

The data collected from secondary sources of Government of India websites were presented and used in this present study. The Table represents the comparison of Petrol price as on $29^{\text {th }}$ September 2018.

\section{Table 1}

COMPARISON CHART FOR PETROL PRICE BEFORE AND AFTER GST PRICES IN TAMILNADU $\left(29^{T H}\right.$ SEPTEMBER 2018)

\begin{tabular}{|l|c|c|}
\hline \multicolumn{1}{|c|}{ Particulars } & Before GST & After GST \\
\hline $\begin{array}{l}\text { International crude oil price (as } \\
\text { on 29th September 2018) }\end{array}$ & $\begin{array}{c}\text { \$ 82.69 or } \\
\text { Rs.5906/Barrel }\end{array}$ & $\begin{array}{c}\text { \$ 82.69 or } \\
\text { Rs.5906/Barrel }\end{array}$ \\
\hline Crude oil per Barrel & 159 Lit & 159 Lit \\
\hline Crude oil - cost per liter & Rs. 37.15/Lit & Rs. 37.15/Lit \\
\hline Cost Calculation of Basic OMC & - & - \\
\hline $\begin{array}{l}\text { Entry Tax, Refinery Processing, } \\
\text { OMC Margin,Freight Cost }\end{array}$ & Rs.3.45/Lit & Rs.3.45/Lit \\
\hline $\begin{array}{l}\text { Basic Fuel Cost after Refining } \\
\text { Cost }\end{array}$ & Rs. 41/Lit & Rs. 41/Lit \\
\hline
\end{tabular}

The table 1 indicates that before and after GST there is no change in the crude oil price instantly. After GST there is no additional excise duty and Road CESS for the petrol was eliminated and GST at the highest lab of $28 \%$ was levied on petrol. The petrol price before Value Added Tax was reduced by $14 \%$ (Rs. 8 ) in the aftermath of GST. Additional VAT for Petrol was eliminated in after the introduction of GST and petrol pump dealer commission was also eliminated in the aftermath of GST in Tamil Nadu. At the outset, The petrol price reduced as compared to before GST introduction in India.

\section{CONCLUSION}

This shows the necessity of implementing GST for the sake of common public. The rate of petrol per liter at current is Rs.86.70 which is Rs.49.55 more than the original cost of petrol before all the tax. Tax alone is $133 \%$ higher than the original cost. It reveals that people pay $43 \%$ for petrol and the remaining $57 \%$ money are paid as tax alone. More political leaders, experts, economists have given their statement which is positive as well as negative. But the point is whether petrol will come under GST or not. Reasons for not implementing GST on petrol is so strong that the state authority will never accept GST as it may cause heave loss in Investment. The price of the petrol may keep on rising as it is fixed by the oil companies. It is in the hands of the Ministers of each and every State and political leaders to agree with GST implementation for the sake of the citizens of our nation.

\section{REFERENCES}

1. Rao, R. K., \& Mukherjee, S. (2019). Goods and Services Tax in India Cambridge University Press.

2. Keshap, P. K. (2015). GST-Goods and Services Tax in India. J Glob Econ, 3, 159.

3. Monika Sehrawat and Upasana Dhanda "GST in India - A key tax reform" International journal of research Granthalya. Vol. 3(Issue 12) (Dec 2015) ISSN- 2350-0530(O) ISSN- 2394-3629(P) Impact Factor: 2.035 (I2OR), http://www.granthaalayah.com, Page No.133-141

4. Mujalde, S., \& Vani, A. (2017). Goods and Service Tax (GST) and its outcome in India. Journal of Madhya Pradesh Economic Association, 27(1), 1-4.

5. Mukherjee, S., \& Rao, R. K. (2019). Exploring Policy Options to Include Petroleum, Natural Gas and Electricity under the Goods and Services Tax (GST) Regime in India. Goods and Services Tax in India, 120. 


\section{AUTHORS PROFILE}

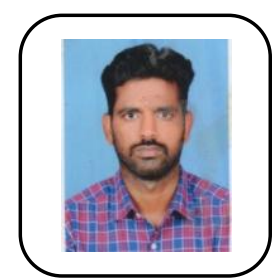

Dr. S. Saravana Kumar is an assistant professor and Head in the Department of Corporate Secretaryship at Annai Therasa Arts \& Science College, Thirukazhukundram. He received his doctorate in commerce from GTN Arts College, Dindigul in the year 2017. His research study is on Marketing on telecom services through BSNL with special reference to Dindigul District. Dr. S. Saravana Kumar has several research publications in well-known international and national journals and conferences.

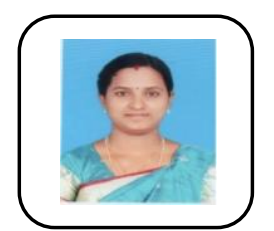

R. Kiruba Shankari is working as an assistant professor in the Department of Corporate Secretaryship at Annai Therasa Arts \& Science College, Thirukazhukundram where she obtained her Master's degree in commerce in the year 2017. She has completed M.Phil. in commerce in the year 2018 and also passed the National Eligibility Test in the same year, on her second attempt. Her research study is on the impact of demonetization on common public with special reference to Chennai city. 